\title{
A111 細胞把持回転装置の小型化とこれを用いた細胞の 3 次元形態観察 \\ Development of a novel cell rotation device and \\ its application to 3D observation of cell morphology
}

\author{
○和家史知 (名工大) 正 長山和亮 (名工大) 正 松本健郎 (名工大)
}

Fuminori WAKE, Nagoya Institute of Technology, Nagoya 466-8555

Kazuaki NAGAYAMA, Nagoya Institute of Technology, Nagoya 466-8555

Takeo MATSUMOTO, Nagoya Institute of Technology, Nagoya 466-8555

\section{1. 緒言}

細胞骨格や細胞小器官が, 細胞内で空間的にどのように配置し ているのかを詳細に知ることは，細胞の機能を明らかにする上で 極めて重要である. 細胞内の 3 次元微細構造は一般的に, 共焦点 レーザ顕微鏡で焦点面をずらした細胞の断層像を複数枚撮影し， 得られた断層像を積み重ねることで求められる. しかし, 細胞内 3 次元微細構造を詳細に観察できる精度の共焦点レーザ顕微鏡は 極めて高価であり，またその再構築像も満足なものとは言えない．

そこで, 我々は細胞内の 3 次元微細構造を比較的安価な装置で 詳細に得ることを目指し，細胞を顕微鏡下で顕微鏡光軸と直交す る軸周りに回転させ，様々な方向から観察した像を元に細胞内 3 次元構造を明らかにする細胞把持回転観察システムの開発を行な ってきだ ${ }^{[1-2]}$. しかし，従来のシステムはピペット先端の位置制 御精度が悪く, 細胞を 1 回転させるのに時間がかが, 満足な観 察ができなかった．本研究では，新たな原理に基づく細胞把持回 転装置を試作し，ピペット先端の位置制御時間の短縮を図るとと もにこれを用いて細胞内の 3 次元微細構造を観察した。

\section{2. 従来の回転観察システム}

従来のシステム(Fig.1)では, 細胞をマイクロガラスピペットで 吸引・把持し, 観察用正立顕微鏡(BX61, オリンパス)の光軸と直 交する軸周りに回転させ，様々な方向からの細胞の回転観察画像 を得ている. 顕微鏡光軸方向を $\mathrm{z}$ 方向, ピペット回転軸方向を $\mathrm{y}$ 方向, 両方の軸と直交する方向を $\mathrm{x}$ 方向と定義する. マイクロピ

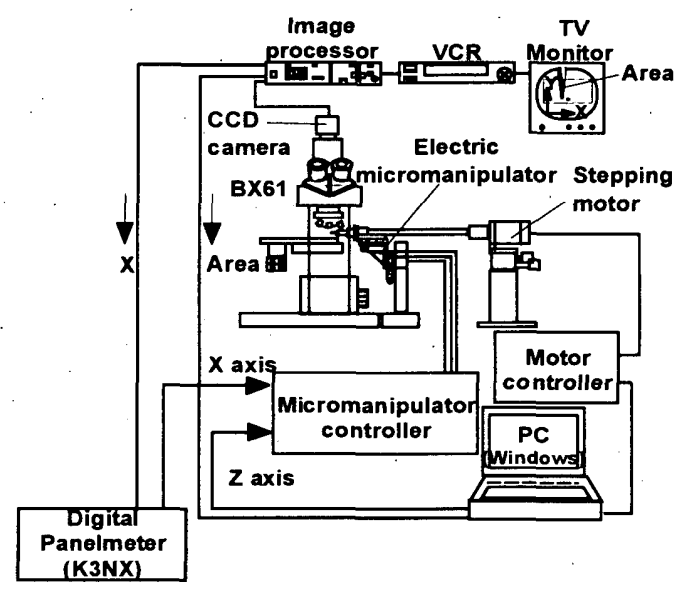

Fig. 1 Schematic diagram of the conventional cell rotation system.
ペット先端の焦点情報, 位置情報は画像処理装置を通して二值化 面積値(Area)と中心座標(X, Y)として出力され, Area が最小とな るように $\mathrm{z}$ 軸マニピュレータを制御し， $(\mathrm{X}, \mathrm{Y})$ がモニタ中心位置 になるように $\mathrm{x}$ ならびに $\mathrm{y}$ 軸マニピュレータを制御することで, ピペット先端位置を画面中心に焦点の合った状態に保った.

このシステムでは，位置制御用マニピュレータのモータがアナ ログ式であるため, 移動量を精密に制御できない, 駆動部がボー ルネジ式のためバックラッシが大きいといった問題から, 細胞内 微細構造観察に不十分な 20 倍対物レンズ下で制御を行なっても, ピペット 1 回転に約 60 秒を要していた. また, 細胞を把持・回 転させる機構部が非常に大きく顕微鏡ステージと独立した配置と なっていたため操作性が悪いといった問題があった.

\section{3. 細胞把持回転装置の小型化と位置制御機構の改良}

本研究では圧電素子を用いた新たな位置制御機構を導入した. 本機構では，ステンレス軸と平行に取り付けた圧電素子を 2 枚の 真鍮円盤で挟み, 圧電素子の伸長をステンレス軸の曲げ変形に変 換し，ピペット先端に増幅して伝達することでピペット先端の位 置制御を行う.また, 圧電素子を回転中心軸周りに回転軸と平行 に $2 つ 90^{\circ}$ ずらして配置することでマイクロピペット先端を $\mathrm{x}-\mathrm{z}$ 平面内で移動させることができる. この方法で圧電素子の変形は 3 倍程度増幅され，ピペット先端の移動量は $50 \mu \mathrm{m}$ 程度になるが, ピペット先端の回転中心軸からのずれは通常 $200 \mu \mathrm{m}$ 以上である ため, 位置制御を行うには不十分である. そこで, 圧電素子後部 にさらにマイクロメータヘッドを取り付けることで, 圧電素子の 変形とは別にピベット先端を移動させ，あらかじめ 1 回転当たり のずれを圧電素子の変形で制御できる範囲に抑えることにした. また，ステンレス軸に半球形の治具 $\mathrm{A}$ を取り付け, 治具の球面

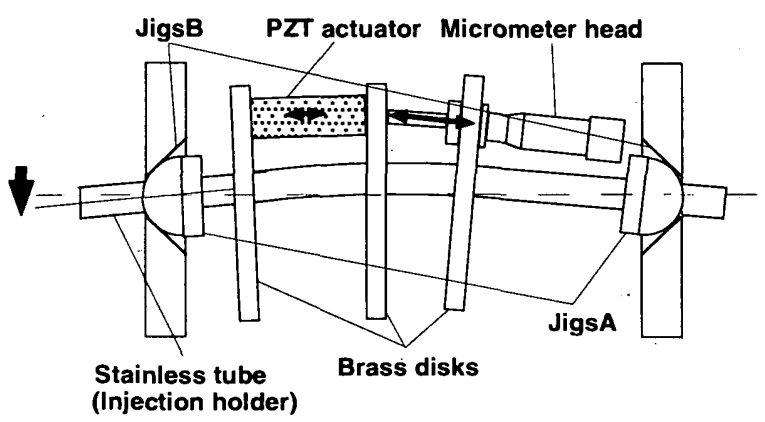

Fig. 2 Schematic diagram of the tube deflection mechanism. A set of mechanism in one of two directions is shown for simplicity.

日本機械学会〔No.04-39〕第15回バイオフロンティア講演会講演論文集（'04.11.6～ 7 宇部市） 
をテーパのついた治具 B に押し付けて回転させる滑り軸受けを 機構部の前後に導入することで, 従来の玉軸受けを用いた片持ち 機構よりも回転に伴うピペット先端のがたつきを抑えながら，圧 電素子とマイクロメータヘッドによるステンレス軸の変形をピペ ット先端に伝達できるようにした，また，ステッピングモータの 回転をベルトとプーリを介してステンレス軸に伝達し，ステンレ ス軸に取り付けたマイクロピペットを顕微鏡光軸と直交する軸周 りに回転させる方式とした.

以上の改良と，ステッピングモータの小型化で細胞把持・回転 機構部を正立顕微鏡ステージに乗る程度まで小型化できた(Fig.3).

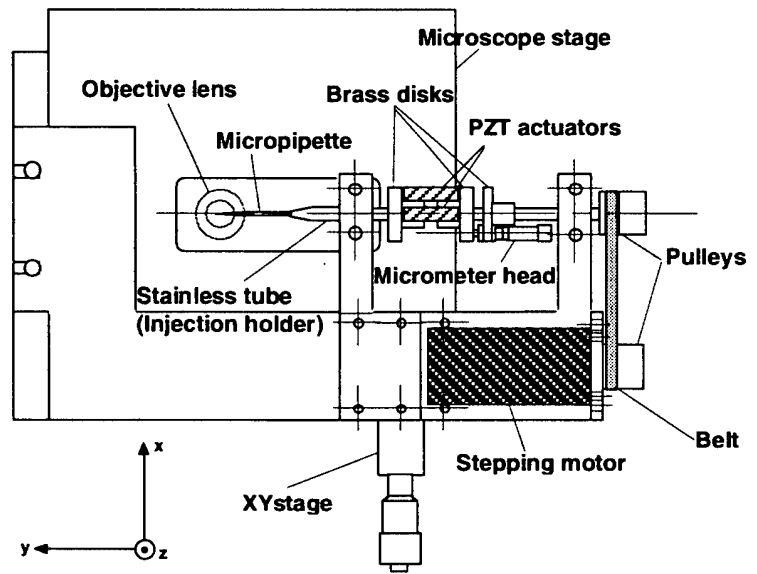

Fig. 3 Schematic diagram of the new cell rotation device.

\section{4. 試作した機構の評価}

試作した機構を用いてピペット先端の位置ずれ制御の評価実験 を行った。あらかじめマイクロメータヘッドによる予備調整を行 なうことで，ピペット先端の位置ずれを制御せずとも 60 倍対物 レンズ視野におさまる程度まで低減することができた(Fig.4).

次に, ピペット回転角度 $36^{\circ}$ 毎に 1 回転分計 10 回の焦点位置, $\mathrm{x}$ 位置を決定するためのキャリブレーションを行った. すなわち， 各角度でピペット先端を焦点位置，モ二タ画面中心位置に制御し たときにそれぞれの圧電素子にかかっている電圧を求め，この電 压をキャリブレーション電圧とした。 その後，求めた 10 組のキ ヤリブレーション電圧を線形補間し 9 毎にオープンループによる 位置制御を行うことで回転中のピペット先端位置制御を行った。

オープンループによる回転中のピペット位置制御によりピペ ット先端に焦点を合わせたまま回転させることができた．また， 従来ピペット 1 回転に 60 秒要していたところを 60 倍対物レンズ を使用しつつ 1 回転 30 秒程度に短縮できた。

\section{5. 細胞の 3 次元形態観察}

試作した装置を用い，トリプシン処理により基板から剥離した ウシ胸大動脈由来培養内皮細胞について $0^{\circ}$ から $360^{\circ}$ まで回転角度 9 毎にピペット位置制御を行い，各角度での画像を撮影した。細 胞はSYTO13 (Molecular Probes)により核を, rhodamine phaloidin (Molecular Probes)によりアクチンフィラメントを二重 染色し，落射蛍光像を撮影した。 Fig.5に $50^{\circ} ， 90^{\circ} ， 180^{\circ} ， 270^{\circ}$ にお ける細胞の明視野像，細胞核およびアクチンフィラメントの蛍光

像を示す。トリプシンにより剥離した細胞核の輪郭形状は各回転 角度で異なり，細胞核が単純な球形ではないということが確認で きた。

\section{6. 結言}

新たな位置制御機構の導入，回転伝達機構の改良，ステッピング モ一タの小型化で装置が顕微鏡ステージ上に乗る程度までの小型化 を実現できた。 また，圧電素子を用いたピペット位置制御機構を導 入することで細胞内微細構造観察に必要な 60 倍対物レンズ下での回 転制御が可能となった。今後は，試作した装置を用いて得られた各 角度における回転画像から X 線 CT スキャンの技術を利用した細胞 内微細構造の3 次元再構築などを行う予定である.

参考文献

[1] 伊藤仙和, 松本健郎, 佐藤正明 : 単離細胞観察のための細胞 把持回転装置の開発，第 13 回バイオエンジニアリング講演会 講演論文集 pp.18-19(2001)

[2] 田島英樹，長山和亮，伊藤仙和，松本健郎，佐藤正明：細胞 回転観察システムの開発と細胞形態の 3 次元観察に関する基 礎検討，日本機械学会東北支部第 38 期総会・講演会講演論文 集 pp.176-177(2003)

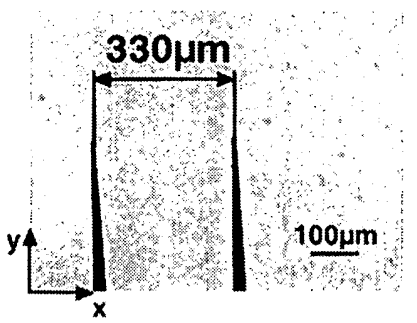

(a) Before adjustment $(\times 10)$

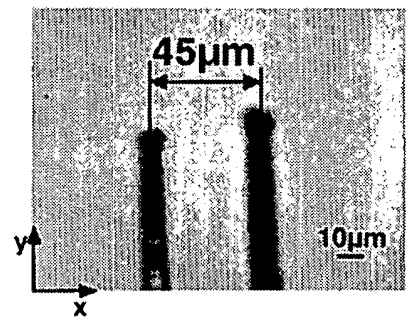

(b) After adjusiment (x60)

Fig. 4 Reduction of the micropipette displacement brought by coarse adjustment with the micrometer heads.
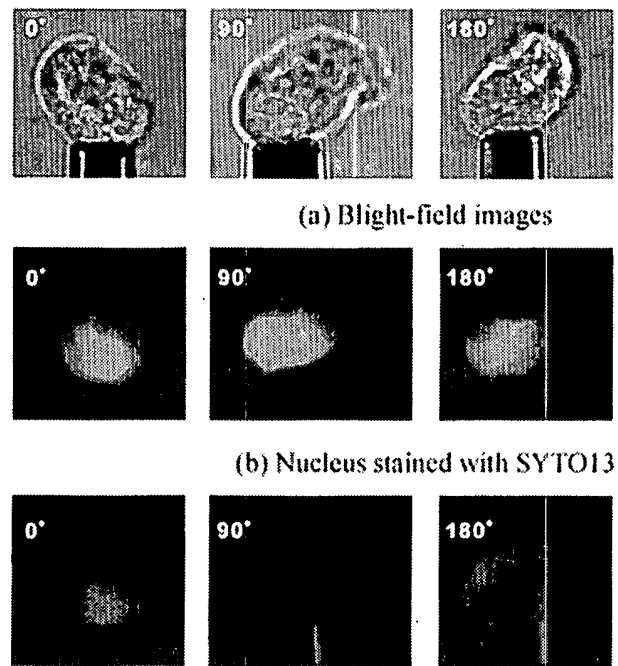

(a) Blight-field images
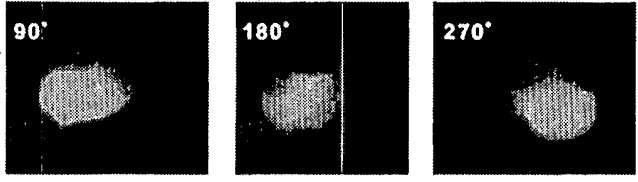

(b) Nucleus stained with SYTO13
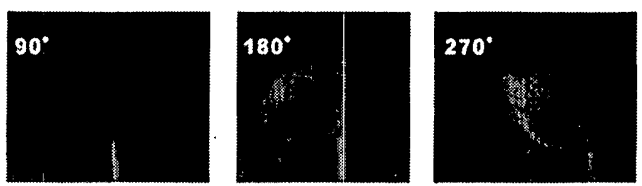

(c) Actin Filaments stained with rodamine phalloidin

Fig. 5 The images of an endothelial cell under rotation. 